\title{
HEPATOPROTECTIVE, ANTIDIABETIC, AND ANTIPYRETIC ACTIVITY STUDIES OF SIDDHA FORMULATION - NILAVEMBU KUDINEER
}

\author{
KASIRAJAN N ${ }^{1 *}$, MAHESHWARI B ${ }^{2}$, SUBASHCHANDRAN G ${ }^{2}$, MAANICKHA CHELVI KS ${ }^{3}$ \\ ${ }^{1}$ Department of Maruthuvam, Tirunelveli, Tamil Nadu, India. ${ }^{2}$ Department of Maruthuvam, Government Siddha Medical \\ College, Palayamkottai, Tirunelveli, Tamil Nadu, India. ${ }^{3}$ Department of Clinical Research, Siddha Regional Research Institute, \\ Thiruvananthapuram, Kerala, India. Email: dr.kasibsms@gmail.com
}

Received: 25 April 2020, Revised and Accepted: 26 June 2020

ABSTRACT

Objective: Traditional medicines like Siddha System of Medicine are one of the most primitive medical system. It plays a major role in treating ailments of humankind. Nowadays, this system flourished throughout India using Nilavembu kudineer (NVK) as a drug to treat in various outbreaks such as dengue, Chikungunya, and other related virus infections. As per literature, NVK indicated many types of fever and various diseases. This study emphasizes on antipyretic, antidiabetic, and hepato protective activities of NVK by In vitro study methods.

Methods: Hepatoprotective effect of NVK on Carbon tetrachloride-induced hepatotoxicity in the rat in five groups, antipyretic activity tested by subcutaneous injection of $10 \mathrm{ml} / \mathrm{kg}$ of $15 \% \mathrm{w} / \mathrm{v}$ yeast suspended in $0.5 \% \mathrm{w} / \mathrm{v}$ carboxymethyl cellulose solution for elevation of body temperature of rats in 6 groups. Antidiabetic activity done by administration of streptozotocin dissolved in citrate buffer (pH 4.5) and nicotinamide, intraperitoneal injection of $60 \mathrm{mg} / \mathrm{kg}$ streptozotocin, $15 \mathrm{~min}$ after the i.p administration of $120 \mathrm{mg} / \mathrm{kg}$ of nicotinamide in non-insulin-dependent diabetes, in six groups.

Results: The hepatoprotective effect having the significance of one way ANOVA followed by Dunnett's $(\mathrm{n}=6)$; ${ }^{\mathrm{n}} \mathrm{p}>0.05, * \mathrm{p}<0.05, * * \mathrm{p}<0.01$, and ${ }^{* * *} \mathrm{p}<0.001$, calculated by comparing treated groups tumor with the control group. Antidiabetic activity having the significance of Dunnett's ${ }^{* * *} \mathrm{p}<0.001,{ }^{* *} \mathrm{p}<0.01$, and ${ }^{*} \mathrm{p}<0.05$ calculated by comparing the treated group with the control group and antipyretic activity results in Dunnett's $* \mathrm{p}<0.05$ calculated by comparing the treated group with the control group were considered to be significant.

Conclusion: The study shows that NVK having the potency of hepatoprotective and capability of diabetes in vitro studies. This study also revealed the potency of antipyretic activity against yeast.

Keywords: Nilavembu kudineer, Hepatoprotective effect, Antidiabetic activity, Antipyretic activity, Statistically significant.

(C) 2020 The Authors. Published by Innovare Academic Sciences Pvt Ltd. This is an open access article under the CC BY license (http://creativecommons. org/licenses/by/4. 0/) DOI: http://dx.doi.org/10.22159/ajpcr.2020.v13i9.38041

\section{INTRODUCTION}

Medicinal plants continue to be an important therapeutic aid for alleviating ailments of humankind. Search for eternal health and longevity and to seek remedy to relieve pain and discomfort prompted the early man to explore his immediate natural surrounding and tried many plants, animal products, and minerals and developed a variety of therapeutic agents. Over a millennium of years that followed, the traditional therapeutic agents among were selected by the process of trial and error, empirical reasoning, and even by experimental tools. These efforts have gone in history by the name discovery of "medicine." In many eastern cultures such as those of India, China, and the Arab/Persian world, this experience systematically recorded and incorporated into a regular system of medicine that refined, developed, and became a part of the Materia Medica of these countries.

Traditional medicines such as Siddha System of Medicine are one of the more primitive medical system. It plays a major role in treating ailments of humankind. The holistic and natural approach toward human illness by Siddha System of Medicine is evident in its use of plants, metals, minerals, and animal products too. This principle plays a major role in diagnosis and treatment and other related areas. Nowadays, this system flourished throughout India using Nilavembu kudineer (NVK) as a drug to treat in various outbreaks such as dengue, Chikungunya, and other related virus infections [1-3] and against other microbes also [4]. The active principle also studied against vector-borne diseases [5]. Hence, the NVK proved for antiviral and antimicrobial activity.

As per Siddha literature, NVK possesses a bitter taste. The bitter taste herbals have more potency to manage diabetes. Most of the antidiabetic drugs also influence liver function. No relevant studies of NVK published regarding this. NVK's antipyretic activity against yeast to be validated scientifically. Hence, this paper focuses on hepatoprotective and antipyretic hypoglycemic activities.

\section{METHODS}

The following drugs used in this preparation should be procured from authenticated sources and verified,

- Nilavembu (Andrographis paniculata)

- Vetiver (Vetiveria zizanioides)

- Vilamichai ver (Plectranthus vettiveroides)

- Santhana thool (Santalum album)

- Peyippudal (Trichosanthes lobata)

- Koraikilangu (Cyperus rotundus)

- Chukku (Zingiber officinale)

- Milagu (Piper nigrum)

- Parpadagam (Hedyotis corymbosa)

In general, aromatic drugs slightly dried to their aroma and willing properties any adulterants materials such as organic and inorganic material removed from the drugs by strict close inspection. All purified nine ingredients and grind into a coarse powder using machineries, this mixture of powder $100 \mathrm{~g}$ mix with $800 \mathrm{ml}$ of water and boiled it. It reduced into $100 \mathrm{ml}$ then filter it.

For all the following pharmacological activities, Wister albino rats weighing 180-200 g collected from Sree Venkateshwara Enterprises, Bengaluru. Animals kept in clean polypropylene cages with $12 \pm 1 \mathrm{~h} \mathrm{light/}$ 
dark schedule and fed with normal pellet (Sai Feed P Ltd., Bengaluru., India) rat chow diet and water ad libitum. The study protocol approved by the Institutional Animals Ethics Committee.

Hepatoprotective effect of $\mathrm{NVK}$ on Carbon tetrachloride $\left(\mathrm{CCl}_{4}\right)$ induced hepatotoxicity in rat

Liver injury due to chemicals (or) infectious agents may lead to progressive liver fibrosis and ultimately cirrhosis and liver failure. $\mathrm{CCl}_{4}$ is widely used for experimental induction of liver damage. The principal causes of $\mathrm{CCl}_{4}$ are induced hepatic damage in lipid peroxidation (LPO) and decreased activities of antioxidant enzymes and the generation of free radicals [6-9].

\section{Experimental design}

The rats randomly divided into five groups of 6 rats each

- Group I: Animals served as normal control and received olive oil 1 $\mathrm{ml} / \mathrm{kg}$ body wt, i.p after every $72 \mathrm{~h}-3$ doses

- Group II: Animals constituted the hepatotoxic group, which received $30 \% \mathrm{CCl}_{4}$ in olive oil $(1 \mathrm{ml} / \mathrm{kg}$ body wt.i.p) after every $72 \mathrm{~h}-3$ doses

- Group III: Animals received $30 \% \mathrm{CCl}_{4}$ in olive oil ( $1 \mathrm{ml} / \mathrm{kg}$ body wti.p) after every $72 \mathrm{~h} 3$ doses + silymarin $100 \mathrm{mg} / \mathrm{kg}$ (po) body wt for 10 days to the $\mathrm{CCl}_{4}$-induced animal

- Group IV: Animals, which received $30 \% \mathrm{CCl}_{4}$ in olive oil $(1 \mathrm{ml} / \mathrm{kg}$ body wt, i.p) after every $72 \mathrm{~h} 3$ doses + NVK $6 \mathrm{ml} / \mathrm{kg}$ (po) body wt for 10 days to the $\mathrm{CCl}_{4}$-induced animal

- Group V: Animals received $30 \% \mathrm{CCl}_{4}$ in olive oil $(1 \mathrm{ml} / \mathrm{kg}$ body $\mathrm{wt}$, i.p) after every $72 \mathrm{~h} 3$ doses + NVK $12 \mathrm{ml} / \mathrm{kg}$ (po) body wt for 10 days to the $\mathrm{CCl}_{4}$-induced animal

- Group VI: Animals, which received $30 \% \mathrm{CCl}_{4}$ in olive oil $(1 \mathrm{ml} / \mathrm{kg}$ body wt, i.p) after every $72 \mathrm{~h} 3$ doses + NVK $18 \mathrm{ml} / \mathrm{kg}$ (po) body wt for 10 days to the $\mathrm{CCl}_{4}$-induced animal.

\section{Antidiabetic activity experimental design}

Animals

The animals fed with standard rat pelleted diet and clean drinking water made available ad libitum.

\section{Induction of diabetes mellitus}

The animal divided into 14 groups of six animals each. The animals maintained overnight fasting to check the initial fasting blood glucose from tip of rat-tail vein. Streptozotocin dissolved in citrate buffer $(\mathrm{pH} 4.5)$ and nicotinamide dissolved in normal saline. Non-insulindependent diabetes mellitus induced in overnight fasted rats by a single intraperitoneal injection of $60 \mathrm{mg} / \mathrm{kg}$ streptozotocin, $15 \mathrm{~min}$ after the i.p administration of $120 \mathrm{mg} / \mathrm{kg}$ of nicotinamide. Hyperglycemia was confirmed by the elevated levels of blood glucose were determined at $72 \mathrm{~h}$. The animals with blood glucose concentration more than $250 \mathrm{mg} / \mathrm{dl}$ selected for the study $[9,10]$.

\section{Study design}

Group 1: Control (normal saline)

Group 2: Streptozotocin $60 \mathrm{mg} / \mathrm{kg} / \mathrm{b} . \mathrm{w}$. (IP) +Nicotinamide $120 \mathrm{mg} / \mathrm{kg}$ (po)

Group 3: Streptozotocin $(60 \mathrm{mg} / \mathrm{kg})+$ Nicotinamide $120 \mathrm{mg} / \mathrm{kg}$ (po) rats treated with Metformin $20 \mathrm{mg} / \mathrm{kg}$ (po)

Group 4: Streptozotocin $(60 \mathrm{mg} / \mathrm{kg})+$ Nicotinamide $120 \mathrm{mg} / \mathrm{kg}$ (po) rats treated with NVK $6 \mathrm{ml} / \mathrm{kg}$ (po)

Group 5: Streptozotocin (60 mg/kg) +Nicotinamide $120 \mathrm{mg} / \mathrm{kg}$ (po) rats treated with NVK12 ml/kg (po)

Group 6: Streptozotocin $(60 \mathrm{mg} / \mathrm{kg})+$ Nicotinamide $120 \mathrm{mg} / \mathrm{kg}$ (po) rats treated with NVK $18 \mathrm{ml} / \mathrm{kg}$ (po).

The vehicle (saline), standard metformin, and test compounds administered to the respective group animals for 28 days. Throughout the study period, metformin, and test compounds freshly dispersed in normal saline and distilled water before to the administration. The fasting animal body and blood glucose level estimated on $1,7^{\text {th }}, 14^{\text {th }}$, $21^{\text {st }}$, and $28^{\text {th }}$ day from tip of rat-tail vein.
Estimation of blood glucose

Blood sample collected from tip of rat-tail vein and glucose levels estimated using glucose oxidase-peroxidase reactive strips and a glucometer (Accu-chek, Roche Diagnostics, USA)

\section{Anti-pyretic activity}

Pyrexia or fever caused as a secondary impact of infection, malignancy, or other diseased states. It is the body's natural function to create an environment where infectious agents or damaged tissues cannot survive. Normally, the infected or damaged tissue initiates the enhanced formation of pro-inflammatory mediators (cytokines, such as interleukin $1 \beta, \alpha, \beta$, and TNF- $\alpha$ ), which increase the synthesis of prostaglandin $\left(\mathrm{PGE}_{2}\right)$ near hypothalamic area and thereby trigger the hypothalamus to elevate the body temperature.

\section{Procedure}

Before yeast injection, the basal rectal temperature of rats recorded, baseline body temperature measured by inserting the digital rectal tele thermometer into the anal cavity of the rat for about $2 \mathrm{~min}$. The steady temperature readings obtained recorded as the pretemperature. After recording animals given a subcutaneous injection of $10 \mathrm{ml} / \mathrm{kg}$ of $15 \% \mathrm{w} / \mathrm{v}$ yeast suspended in $0.5 \% \mathrm{w} / \mathrm{v}$ carboxymethyl cellulose solution for the elevation of body temperature of rats. Rats returned to their home cages. Eighteen hours after yeast injection, rats with elevated body temperature selected for grouping and the NVK and standard drug suspended in CMC and administered by gastric tube.

\section{Animal grouping}

Group I- Negative control - injected with $10 \mathrm{ml} / \mathrm{kg}$ of $15 \% \mathrm{w} / \mathrm{v}$ yeast given (sc injection)

Group II- Yeast+ Standard paracetamol (150 mg/kg) p.o

Group III- Yeast + NVK $6 \mathrm{ml} / \mathrm{kg}$

Group IV- Yeast + NVK $12 \mathrm{ml} / \mathrm{kg}$

Group V- Yeast + NVK $18 \mathrm{ml} / \mathrm{kg}$.

Rectal temperature was recorded by a digital rectal thermometer at 0 , $1,2,3,4,5$, and $6 \mathrm{~h}$ after drug administration.

\section{RESULTS}

Effect of NVK on body weight and liver weight (physical parameter) (Tables 1 and 2)

The animals in 6 groups treated with $\mathrm{CCl}_{4}$ and $\mathrm{NVK}$ with various doses produce significant changes in body weight and liver weight. Treatment with $\mathrm{CCl}_{4}$ resulted in rising body weight; NVK administration reduced the weight gain back to normal. Moreover, body weight levels of all groups are near to the control group except $\mathrm{CCl}_{4}$-treated group. Fatty changes in the liver produced by $\mathrm{CCl}_{4}$, which resulted in a reduction of liver weight, NVK at $12 \mathrm{ml}$ dose increased the liver weight close to the control group.

\section{Effect of NVK on biochemical parameters (Table 3 )}

The toxicant $\mathrm{CCl}_{4}$ administration showed distinct changes in liver enzymes such as serum glutamic-oxaloacetic transaminase (SGOT), serum glutamic pyruvic transaminase (SGPT), alkaline phosphatase (ALP), and acid phosphatase (AcP) shown in Table 3, also increased bilirubin level. NVK administration carried out in three dose levels $6 \mathrm{ml}$, $12 \mathrm{ml}$, and $18 \mathrm{ml}$. All three doses range showed a significant reduction in the elevated enzyme levels. At the high dose, $18 \mathrm{ml}$ produced the reduction of enzymes among the three doses.

\section{Effect of NVK on in vivo antioxidants (Table 4)}

The toxicant $\mathrm{CCl}$ injures the hepatic cells and causes significant damage to liver. As a result, there is a significant reduction, $50 \%$ lower than the control group shown in Table 4. The effect of NVK on antioxidant status increased the levels superoxide dismutase, glutathione (GSH) peroxidase, GSH, and LPO and restored near to normal levels. NVK significantly restored the depleted GSH and GPX levels, similar to that of the control group at $12 \mathrm{ml}$ and $18 \mathrm{ml}$ doses. 
Table 1: Effect of NVK on body weight

\begin{tabular}{|c|c|c|c|c|c|c|}
\hline Group & Control (1 ml/kg) & $\begin{array}{l}\text { Only } \mathrm{CCl}_{4} \\
(1 \mathrm{ml} / \mathrm{kg})\end{array}$ & $\begin{array}{l}\mathrm{CCl}_{4}+\mathrm{Std} \\
(100 \mathrm{mg} / \mathrm{kg})\end{array}$ & $\begin{array}{l}\mathrm{CCl}_{4}+\mathrm{NVK} \mathrm{low} \\
\text { dose }(6 \mathrm{ml} / \mathrm{kg})\end{array}$ & $\begin{array}{l}\mathrm{CCl}_{4}+\mathrm{NVK} \mathrm{middle} \\
\text { dose }(12 \mathrm{ml} / \mathrm{kg})\end{array}$ & $\begin{array}{l}\mathrm{CCl}_{4}+\mathrm{NVK} \text { high } \\
\text { dose }(18 \mathrm{ml} / \mathrm{kg})\end{array}$ \\
\hline In body weight (g) & $134 \pm 2.129$ & $139.7 \pm 2.704$ & $121.8 \pm 0.9098$ & $129.3 \pm 1.229$ & $126.7 \pm 0.8028$ & $125.3 \pm 1.116$ \\
\hline $7^{\text {th }}$ day $(\mathrm{g})$ & $147.8 \pm 2.197$ & $150 \pm 2.933$ & $143.2 \pm 1.249$ & $142.7 \pm 1.308$ & $141.3 \pm 1.202$ & $142.5 \pm 1.088$ \\
\hline $14^{\text {th }}$ day (g) & $165.7 \pm 1.874$ & $169.7 \pm 2.512$ & $152 \pm 1.414$ & $152.5 \pm 1.586$ & $151.3 \pm 0.7601$ & $153 \pm 1.528$ \\
\hline
\end{tabular}

Values are expressed as mean \pm SEM, $(n=6)$, comparing treated groups tumor with a control group. Analysis by one way ANOVA followed by Dunnett's test; Significant at $\mathrm{p}>0.05,{ }^{*} \mathrm{p}<0.05,{ }^{* *} \mathrm{p}<0.01,{ }^{* * *} \mathrm{p}<0.001$. NVK: Nilavembu kudineer. $\mathrm{CCl}_{4}$ : Carbon tetrachloride

Table 2: Effect of NVK on liver weight

\begin{tabular}{|c|c|c|c|c|c|c|}
\hline Group & $\begin{array}{l}\text { Control } \\
(1 \mathrm{ml} / \mathrm{kg})\end{array}$ & $\begin{array}{l}\text { Only } \mathrm{CCl}_{4} \\
(1 \mathrm{ml} / \mathrm{kg})\end{array}$ & $\begin{array}{l}\mathrm{CCl}_{4}+\mathrm{Std} \\
(100 \mathrm{mg} / \mathrm{kg})\end{array}$ & $\begin{array}{l}\mathrm{CCl}_{4}+\mathrm{NVK} \text { low dose } \\
(6 \mathrm{ml} / \mathrm{kg})\end{array}$ & $\begin{array}{l}\mathrm{CCl}_{4}+\mathrm{NVK} \mathrm{middle} \\
\text { dose }(12 \mathrm{ml} / \mathrm{kg})\end{array}$ & $\begin{array}{l}\mathrm{CCl}_{4}+\mathrm{NVK} \text { high dose } \\
(18 \mathrm{ml} / \mathrm{kg})\end{array}$ \\
\hline Liver weight (g) & $8.09 \pm 0.4486$ & $4.505 \pm 0.2188^{* * *}$ & $4.814 \pm 0.3156^{* * *}$ & $4.003 \pm 0.6874^{* * *}$ & $5.27 \pm 0.4206^{* * *}$ & $4.755 \pm 0.2656^{* * *}$ \\
\hline
\end{tabular}

Values are expressed as mean \pm SEM $(n=6)$, comparing treated groups, tumor with the control group. Analysis by one way ANOVA followed by Dunnett's test; significant at $\mathrm{p}>0.05,{ }^{*} \mathrm{p}<0.05,{ }^{* *} \mathrm{p}<0.01,{ }^{* * *} \mathrm{p}<0.001$. NVK: Nilavembu kudineer. $\mathrm{CCl}_{4}$ : Carbon tetrachloride

Table 3: Effect of NVK on biochemical parameters

\begin{tabular}{|c|c|c|c|c|c|c|}
\hline Group & $\begin{array}{l}\text { Control } \\
(1 \mathrm{ml} / \mathrm{kg})\end{array}$ & $\begin{array}{l}\text { Only } \mathrm{CCl}_{4} \\
(1 \mathrm{ml} / \mathrm{kg})\end{array}$ & $\begin{array}{l}\mathrm{CCl}_{4}+\mathrm{Std} \\
(100 \mathrm{mg} / \mathrm{kg})\end{array}$ & $\begin{array}{l}\mathrm{CCl}_{4}+\mathrm{NVK} \mathrm{low} \\
\text { dose }(6 \mathrm{ml} / \mathrm{kg})\end{array}$ & $\begin{array}{l}\mathrm{CCl}_{4}+\mathrm{NVK} \mathrm{middle} \\
\text { dose }(12 \mathrm{ml} / \mathrm{kg})\end{array}$ & $\begin{array}{l}\mathrm{CCl}_{4}+\mathrm{NVK} \text { high } \\
\text { dose }(18 \mathrm{ml} / \mathrm{kg})\end{array}$ \\
\hline Total bilirubin (g/dl) & $0.7733 \pm 0.06211$ & $1.467 \pm 0.1627$ & $0.7767 \pm 0.0559$ & $0.89 \pm 0.01897$ & $0.8067 \pm 0.08628$ & $0.8567 \pm 0.04104$ \\
\hline SGOT (U/L) & $118.3 \pm 1.142$ & $230.4 \pm 4.113^{* * *}$ & $134.7 \pm 1.774^{* * *}$ & $165.7 \pm 1.79 * * *$ & $167.8 \pm 1.99^{* * *}$ & $158.4 \pm 2.032^{* * *}$ \\
\hline SGPT (U/L) & $46.17 \pm 1.515$ & $118.4 \pm 2.436^{* * *}$ & $61.63 \pm 1.312$ & $71.53 \pm 1.064^{* *}$ & $65.27 \pm 1.571^{*}$ & $64.05 \pm 1.957$ \\
\hline ALP (U/L) & $63.3 \pm 0.9317$ & $161.2 \pm 1.301$ & $72.03 \pm 1.468$ & $84.3 \pm 1.554$ & $84.77 \pm 1.168$ & $79.3 \pm 1.43$ \\
\hline Acp (U/L) & $5.184 \pm 0.283277$ & $12.92 \pm 0.877724^{* * *}$ & $7.56 \pm 0.40694$ & $9.1 \pm 0.801873^{*}$ & $9.48 \pm 1.347^{* *}$ & $7.9 \pm 0.884873$ \\
\hline
\end{tabular}

Values are expressed as mean \pm SEM, $(n=6)$, comparing treated groups tumor with control group. Analysis by one way ANOVA followed by Dunnett's test; significant at $\mathrm{p}>0.05,{ }^{*} \mathrm{p}<0.05,{ }^{* *} \mathrm{p}<0.01,{ }^{* * *} \mathrm{p}<0.001$. NVK: Nilavembu kudineer, SGOT: Serum glutamic-oxaloacetic transaminase, SGPT: Serum glutamic pyruvic transaminase. CCl ${ }_{4}$ Carbon tetrachloride

Table 4: Effect of NVK on in vivo antioxidants

\begin{tabular}{|c|c|c|c|c|c|c|}
\hline Group & $\begin{array}{l}\text { Control } \\
(1 \mathrm{ml} / \mathrm{kg})\end{array}$ & $\begin{array}{l}\text { Only } \mathrm{CCl}_{4} \\
(1 \mathrm{ml} / \mathrm{kg})\end{array}$ & $\begin{array}{l}\mathrm{CCl}_{4}+\mathrm{Std} \\
(100 \mathrm{mg} / \mathrm{kg})\end{array}$ & $\begin{array}{l}\mathrm{CCl}_{4}+\mathrm{NVK} \mathrm{low} \\
\text { dose }(6 \mathrm{ml} / \mathrm{kg})\end{array}$ & $\begin{array}{l}\mathrm{CCl}_{4}+\mathrm{NVK} \text { middle } \\
\text { dose }(12 \mathrm{ml} / \mathrm{kg})\end{array}$ & $\begin{array}{l}\mathrm{CCl}_{4}+\mathrm{NVK}_{\mathrm{high}} \\
\text { dose }(18 \mathrm{ml} / \mathrm{kg})\end{array}$ \\
\hline SOD (unit/min/mg) & $5.8 \pm 0.2352$ & $6.167 \pm 0.08433^{* * *}$ & $3.117 \pm 0.1851^{* * *}$ & $4.467 \pm 0.2565^{* * *}$ & $4.767 \pm 0.09888$ & $4.8 \pm 0.2309$ \\
\hline Catalysis $(\mu \mathrm{mol} / \mathrm{min} / \mathrm{mg})$ & $89.33 \pm 1.687$ & $90.33 \pm 1.542^{* * *}$ & $53.33 \pm 0.9545$ & $74.33 \pm 2.642^{* * *}$ & $78 \pm 0.9661^{* * *}$ & $78.17 \pm 1.493$ \\
\hline $\mathrm{GPX}(\mu \mathrm{m} / \mathrm{min} / \mathrm{mg})$ & $44.5 \pm 0.922$ & $49.83 \pm 0.7923 * * *$ & $22.83 \pm 0.7032$ & $34.5 \pm 1.057^{* * *}$ & $40.83 \pm 0.7923$ & $41.33 \pm 1.909$ \\
\hline $\mathrm{GSH}(\mu \mathrm{g} / \mathrm{mg})$ & $32 \pm 0.5164$ & $15.83 \pm 0.7032$ & $38.83 \pm 0.6009$ & $21.83 \pm 0.4773$ & $32.33 \pm 0.6667 * * *$ & $33.5 \pm 0.9574^{* * *}$ \\
\hline LPO $(\mu \mathrm{g} / \mathrm{mg})$ & $9.833 \pm 0.3073$ & $40.17 \pm 0.4773$ & $15.33 \pm 0.4216$ & $26.5 \pm 0.5627$ & $23.33 \pm 0.4944$ & $22.5 \pm 0.7638$ \\
\hline
\end{tabular}

Values are expressed as mean \pm SEM, $(n=6)$; comparing treated groups tumor with control group. Analysis by one way ANOVA followed by Dunnett's test; significant at $\mathrm{p}>0.05,{ }^{*} \mathrm{p}<0.05,{ }^{* *} \mathrm{p}<0.01,{ }^{* * *} \mathrm{p}<0.001$. NVK: Nilavembu kudineer, SOD: Superoxide dismutase, GPX: Glutathione peroxidase, LPO: Lipid peroxidation. CCl ${ }_{4}$ : Carbon tetrachloride

Effect of NVK on body weight in normal and diabetic rats (Table 5) Streptozotocin- and nicotinamide-induced diabetic rat's body weight results showed in Table 5. The body weight of streptozotocin and metformin group increased in the first 2 weeks and gradually decreased after that. The NVK administration at various doses resulted with the same weight after 2 weeks as a control group throughout the study period and statistically significant.

Effect of NVK on blood glucose level in normal and diabetic rats (Table 6)

Streptozotocin- and nicotinamide-induced diabetes result in a significant rise of blood glucose levels. NVK treatment produces a significant effect in the reduction of blood sugar level when compared to standard medicine; this effect is highly appreciated at $12 \mathrm{ml}$ and $18 \mathrm{ml}$ doses $(\mathrm{p}<0.01)$. The later days of treatment effectively controlled by NVK than initial days.

Effect of NVK on Brewer's yeast-induced pyrexia in rats (Table 7) The treatment with yeast produced the desired effect of fever, which is controlled by the NVK administration and produced a significant reduction in body temperature within $30 \mathrm{~min}(\mathrm{p}<0.05)$. The lower dose $6 \mathrm{ml}$ of NVK showed a marked reduction in temperature when compared to the paracetamol treated group. The trial drug NVK proved good antipyretic activity at low dose.

\section{DISCUSSION}

Either human beings exposed to various chemicals and chemical products directly or indirectly, lifestyle habits such as alcohol, which causes liver damage. The clinical symptoms and significant changes in the liver functions will be noticed in advance liver damage of hepatocytes. Liver damage may lead to hepatitis, non-alcoholic liver disease, portal hypertension, cirrhosis, Wilson's disease, and hepatocellular carcinoma [11-15]. $\mathrm{CCl}_{4}$ is one of the most commonly used hepatotoxins in the experimental study of liver diseases for its active metabolite and trichloromethyl radical $[16,17] . \mathrm{CCl}_{4}$ administered rats show increased levels of bilirubin, increased levels of SGOT, SGPT, and ALP were a strong indication of the cellular leakage and loss of cell membrane integrity. When treated with NVK, inhibited the LPO, reduced the cellular damage, and protected and stabilize the functions of cell, maintain the enzymes, and bilirubin level normal limits. Since the polyphenols are known to inhibit the activity of GST enzymes, there may be a competition between the two for the active site of the enzyme [18]. This pathway also confirmed by the NVK effect in antioxidant levels results and formulation had polyphenols. NVK with a medium dose level gave the desired effect compared to other doses. Likewise, $\mathrm{CCl}_{4}$ treatment reduced body weight due to hepatotoxicity fatty changes. NVK prevents hepatocellular damage and improves the function of liver leads to increase liver weight and metabolism also enhanced. 
Table 5: Effect of NVK on body weight in normal and diabetic rats

\begin{tabular}{|c|c|c|c|c|c|}
\hline Groups & $\begin{array}{l}\text { Initial body } \\
\text { weight (g) }\end{array}$ & $\begin{array}{l}\text { Body weight } 1^{\text {st }} \\
\text { wk (g) }\end{array}$ & $\begin{array}{l}\text { Body weight } 2^{\text {nd }} \\
\text { wk (g) }\end{array}$ & $\begin{array}{l}\text { Body weight } 3^{\text {rd }} \\
\text { wk (g) }\end{array}$ & $\begin{array}{l}\text { Body weight } 4^{\text {th }} \\
\text { wk (g) }\end{array}$ \\
\hline Control & $114.83 \pm 1.424$ & $122.5 \pm 1.310$ & $130.33 \pm 1.666$ & $141 \pm 1.527$ & $148 \pm 1.06458$ \\
\hline Only STZ (60 mg/kg) & $133 \pm 0.856$ & $142.17 \pm 1.275$ & $132 \pm 0.894$ & $123.5 \pm 0.957$ & $120.333 \pm 1.3081$ \\
\hline STZ + Glibenclamide $(20 \mathrm{mg} / \mathrm{kg})$ & $123.33 \pm 1.229$ & $133.16 \pm 1.514$ & $122.33 \pm 0.954$ & $131 \pm 1.527$ & $138 \pm 2.129$ \\
\hline STZ + NVK.L.D (6 ml/kg) & $127 \pm 1.632$ & $133.33 \pm 1.837$ & $139.16 \pm 1.815$ & $143.5 \pm 1.648$ & $148.67 \pm 1.145$ \\
\hline STZ + NVK M.D (12 ml/kg) & $122 \pm 1.549$ & $130 \pm 1.632$ & $136.16 \pm 1.275$ & $142.67 \pm 1.115$ & $150.83 \pm 1.046$ \\
\hline STZ + NVK.H.D (18 ml/kg) & $117.5 \pm 0.5$ & $123.66 \pm 1.201$ & $134.17 \pm 1.275$ & $143 \pm 1.154$ & $148.67 \pm 1.358$ \\
\hline
\end{tabular}

Values expressed as the mean \pm S.D; statistical significance (p) calculated by one-way ANOVA followed by Dunnett's ${ }^{* * *} \mathrm{p}<0.001,{ }^{* *} \mathrm{p}<0.01,{ }^{*} \mathrm{p}<0.05$ calculated by comparing treated group with control group. NVK: Nilavembu kudineer

Table 6: Effect of NVK on blood glucose level in normal and diabetic rats

\begin{tabular}{|c|c|c|c|c|c|}
\hline Groups & Initial blood sugar & $\begin{array}{l}\text { Blood sugar } \\
\text { fasting } 72 \mathrm{~h}\end{array}$ & $\begin{array}{l}\text { Blood sugar } \\
\text { fasting } 10^{\text {th }} \text { day }\end{array}$ & $\begin{array}{l}\text { Blood sugar } \\
\text { fasting } 15^{\text {th }} \text { day }\end{array}$ & $\begin{array}{l}\text { Blood sugar fasting } \\
28^{\text {th }} \text { day }\end{array}$ \\
\hline Control & $76.3333 \pm 2.66667$ & $71.333 \pm 5.407$ & $72.33 \pm 5.070$ & $72.33 \pm 5.07061$ & $70.6667 \pm 2.36173$ \\
\hline Only STZ & $80 \pm 4.131$ & $463.33 \pm 47.164^{* * *}$ & $368.33 \pm 25.353^{* * *}$ & $326.67 \pm 23.8979^{* * *}$ & $306.66 \pm 24.44^{* * *}$ \\
\hline STZ + Glibenclamide & $85.33 \pm 5.919$ & $426.66 \pm 52.578^{* * *}$ & $331.67 \pm 36.001^{* *}$ & $248.33 \pm 17.966^{* * *}$ & $128.333 \pm 11.3774^{*}$ \\
\hline STZ + NVK.L.D $6 \mathrm{ml}$ & $77.5 \pm 4.232$ & $376.67 \pm 52.451^{* *}$ & $288.33 \pm 40.85^{*}$ & $226.67 \pm 24.720^{* * *}$ & $148.33 \pm 17.207^{* *}$ \\
\hline STZ + NVK M.D $12 \mathrm{ml}$ & $77.5 \pm 4.256$ & $430 \pm 57.677^{* * *}$ & $303.333 \pm 37.475^{* *}$ & $201.67 \pm 15.5813^{* *}$ & $126.67 \pm 12.56^{*}$ \\
\hline STZ + NVK.H.D $18 \mathrm{ml}$ & $79.33 \pm 5.607$ & $413.33 \pm 56.312^{* * *}$ & $335 \pm 50.711^{* * *}$ & $198.33 \pm 9.45751^{*}$ & $141.67 \pm 11.377^{* *}$ \\
\hline
\end{tabular}

Values expressed as mean $\pm \mathrm{SD}$, comparing treated group with control group. Analysis by one way ANOVA followed by Dunnett's test; significant at * $<<0.05$. NVK: Nilavembu kudineer

Table 7: Effect of NVK on Brewer's yeast-induced pyrexia in rats

\begin{tabular}{|c|c|c|c|c|c|}
\hline \multirow[t]{3}{*}{ Group } & \multirow{3}{*}{$\begin{array}{l}\begin{array}{l}\text { Rectal } \\
\text { temperature }\end{array} \\
\text { Initial (A) }\end{array}$} & \multicolumn{4}{|c|}{ Rectal temperature $(8 \mathrm{~h})$ after induction with yeast } \\
\hline & & \multirow{2}{*}{$\begin{array}{l}\text { Body temperature after } 8 \mathrm{~h} \\
\text { induction with yeast (F) } \\
8^{\text {th }} \mathrm{h}(\mathrm{B})\end{array}$} & \multicolumn{3}{|c|}{$\begin{array}{l}\text { Body temperature after } 8 \mathrm{~h} \text { induction with } \\
\text { yeast (F) }\end{array}$} \\
\hline & & & $30^{\text {th }} \min$ & $60^{\text {th }} \min$ & $120^{\text {th }} \min$ \\
\hline Only yeast ( $10 \mathrm{ml} / \mathrm{kg}$ of $15 \% \mathrm{w} / \mathrm{v}$ ) & $32.5 \pm 1.708$ & $39.5 \pm 1.5$ & $36.25 \pm 0.8539$ & $32.75 \pm 0.4787$ & $32 \pm 0.8165$ \\
\hline Yeast + Std $(150 \mathrm{mg} / \mathrm{kg})$ & $33 \pm 1.291$ & $33 \pm 1.291$ & $32.5 \pm 1.258$ & $32.75 \pm 0.8539$ & $32 \pm 0.4082$ \\
\hline Yeast + L.D (6 ml $/ \mathrm{kg})$ & $32.25 \pm 1.652$ & $34.5 \pm 1.708$ & $31 \pm 1.291$ & $31.75 \pm 1.652$ & $31.5 \pm 1.555$ \\
\hline Yeast + M.D (12 ml/kg) & $34 \pm 0.8165$ & $33.5 \pm 1.5$ & $34.5 \pm 1.708$ & $33.75 \pm 1.493$ & $34 \pm 0.9129$ \\
\hline Yeast + H.D (18 ml/kg) & $33 \pm 1.291$ & $34.25 \pm 2.323$ & $37 \pm 0.4082$ & $36.25 \pm 0.8539$ & $33.75 \pm 0.4787$ \\
\hline
\end{tabular}

Values expressed as mean \pm SD, comparing treated group with control group. Analysis by one way ANOVA followed by Dunnett's test; significant at * $<<0.05$. NVK: Nilavembu kudineer

Metabolic activation of $\mathrm{CCl}_{4}$ by cytochrome P450-dependent mixed oxidase in the endoplasmic reticulum to form a trichloromethyl free radical $\left(\mathrm{CCl}_{3}\right)$ leads to severe damage to liver cells. It also combines with cellular lipids and proteins in the presence of oxygen to induce LPO $[18,19]$. In states of oxidative stress, GSH converted to GSH disulfide and depleted, leading to LPO. Therefore, the role of GSH as a reasonable marker for the evaluation of oxidative stress is important [18-20]. Since the polyphenols are known to inhibit the activity of GST enzymes, there may be a competition between the two for the active site of the enzyme NVK inhibited LPO and elevated depleted serum GSH levels to normal limits. NVK formulation had constituent of andrographolide derived from A. paniculata possess liver protection under various experimental conditions of treatment with galactosamine [21]. Among the remaining eight herbals, ginger, pepper, and nutgrass may possess add on effect for this antioxidant property.

The antidiabetic activity of NVK well established from above streptozotocin-induced diabetes. The NVK treated diabetic rats study showed that NVK results in a marked decrease in blood glucose in diabetic rats after 28 days of treatment. This may be due to an increase in the release of insulin from $\beta$-cells of pancreas. Loss of body weight in a diabetic is an indication of damage of tissue proteins in abnormal levels. Decreased body weight observed in the streptozotocin-treated group. Treatment with NVK improved body weight, indicating that control over tissue protein damage and muscle wasting resulted from glycemic control. The herbals of this formulation such as green chiretta, ginger, and nutgrass have active metabolites that possess antidiabetic activity [22-24]. This suggests the hypoglycemic effect of NVK in diabetic rats.
The NVK effect against viral fevers like those that dengue and Chikungunya proved scientifically by various in vitro and in vivo studies [25,26]; however, no data available regarding the antipyretic effect against yeast-induced fever. Hence, this study showed that NVK has a significant effect of reducing fever. This may be due to $\mathrm{COX}_{2}$ inhibition and binding with $\mathrm{PGE}_{2}[26,27]$. It may be confirmed by clinical trials in the future.

\section{CONCLUSION}

In the above studies, hepatoprotective activity carried out using $\mathrm{CCL}_{4}{ }^{-}$ induced hepatotoxicity in rat. The trial drug NVK having significant hepatoprotective activity also reveals the effectiveness of NVK in treating liver diseases. Hypoglycemic activity of the trial drug NVK on streptozotocin and nicotinamide induced type-II diabetic rats. This study reveals NVK decoction possesses good control of blood sugar levels and significant antidiabetic activity. Antipyretic activity of the trial drug NVK carried out using the yeast-induced method. The drug NVK showed potent antipyretic activity. Overall study results torching light in the treatment of diabetes, hepatoprotective effect, and reducing the fever.

\section{CONFLICTS OF INTEREST}

The author declares no conflicts of interest.

\section{AUTHORS' CONTRIBUTIONS}

Kasirajan N - Conception of the work and data collection. Maheshwari B - Conception of the work and data collection. Subashchandran 
G - Drafting the article. Maanickha Chelvi K S - Data analysis and interpretation.

\section{AUTHORS' FUNDING}

Nil.

\section{REFERENCES}

1. Jain J, Kumar A, Narayanan V, Ramaswamy RS, Sathiyarajeswaran P, Devi MS, et al. Antiviral activity of ethanolic extract of nilavembu kudineer against dengue and chikungunya virus through in vitro evaluation. J Ayurveda Integr Med 2018;1:76-80.

2. Sathya B, Velpandian V, Ramani M, Kumar A. Primitive approach on review of siddha herbs, herbo-mineral formulation exhibiting antiviral activity. Int J Pharma Bio Sci 2014;5:138-47.

3. Christian GJ, Subramanian M, Periyasami D, Manickavasakam K, Gunasekaran P, Sivasubramanian S, et al. Protective effect of polyherbal siddha formulation-nilavembu kudineer against common viral fevers including dengue-a case control approach. IJPSR 2015;6:1656-60.

4. Uma KS, Jacob M, Arumugam G, Kalpana S, Natarajan M. In vitro Antimicrobial activity of the siddha drugs seenthil Sarkarai and nilavembu kudineer against Leptospira. Int J Pharm Pharm Sci 2012;4:75-8.

5. Sahabudeen S, Nag H, Madhavan S, Chatterjee A, Dan P, Bhattacharya $\mathrm{M}$, et al. Fecundity studies of Andrographis paniculata on Drosophila melanogaster. Int J Pharm Pharm Sci 2019;11:23-7.

6. Maiti K, Mukherjee K, Murugan V, Saha BP, Mukherjee PK. Enhancing bioavailability and hepato protective activity of andrographolide from Andrographis paniculata, a well-known medicinal food, through its herbo some. J Sci Food Agric 2010;90:43-51.

7. Castro JA, De Ferreyra EC, De Castro CR, De Fenos OM, Sasame H, Gillette JR. Prevention of carbon tetrachloride-induced necrosis by inhibitors of drug metabolism-further studies on their mechanism of action. Biochem Pharmacol 1974;23:295-2.

8. Parola M, Leonarduzz G, Biasi F, Albono M, Biocca G, Dianzani MU. Vitamin E dietary supplementation. Protects against CCl4 induced chronic liver damage and cirrhosis. Hepatology 1992;16:1014-21.

9. Poli G. Liver damage due to free radicals. Br Med Bull 1993:49:604-20.

10. Marudamuthu AS, Leelavinothan P. Effect of pterostilbene on lipids and lipid profiles for diabetes, in streptozotocin-nicotinamide induced Type 2 diabetes mellitus. J Appl Biomed 2008;6:31-7.

11. Singh A, Bhat TK, Sharma OP. Clinical biochemistry of hepatotoxicity. J Clin Toxicol 2011;4:210-7

12. Pandit A, Sachdeva T, Bafna P. Drug-induced hepatotoxicity: A review.
J Appl Pharm Sci 2012;2:233-43

13. Kumar A. A review on hepatoprotective herbal drugs. IJRPC 2012;2:92-2.

14. Seeff LB, Lindsay KL, Bacon BR, Kresina TF, Hoofnagle JH. Complementary and alternative medicine in chronic liver disease. Hepatology 2001;34:595-3.

15. Dhingra M, Nain P, Nain J, Malik M. Hepatotoxicity v/s hepato protective agents-a pharmacological review. IRJP 2011;2:31-7.

16. Johnston DE, Kroening C. Mechanism of early carbon tetrachloride toxicity in cultured rat hepatocytes. Pharmacol Toxicol 1998;83:231-9.

17. Srivastava SP, Chen NO, Holtzman JL. The in vitro NADPH dependent inhibition by $\mathrm{CCl} 4$ of the ATP-dependent calcium uptake of hepatic microsomes from male rats. Studies on the mechanism of inactivation of the hepatic microsomal calcium pump by the $\mathrm{CCl} 3$ radical. J Biol Chem 1990;265:8392-9.

18. Recknagel RO, Glende EA, Hruszkewycz AM. Free Radicals in Biology. Vol. 3. New York: Academic Press; 1977. p. 97-32.

19. De Groot H, Noll T. The crucial role of low steady state oxygen partial pressures in haloalkane free-radical mediated lipid peroxidation. Biochem Pharmacol 1986;35:15.

20. Al-Harbi MS. Hepatoprotective effect and antioxidant capacity of naringenin on arsenic-induced liver injury in rats. Int J Pharm Pharm Sci 2016;8:103-8.

21. Saxena S, Jain DC, Gupta MM, Bhakuni RS, Mishra HO, Sharma RP. High-performance thin-layer chromatographic analysis of hepatoprotective diterpenoids from Andrographis paniculata. Phytochem Anal 2000;11:34-6.

22. Putta W, Chedalawada V. Dose dependent effect on hypoglycemic and antihyperglycemic activities of chloroform extract of physalis minima in streptozotocin induced diabetic rats. Int J Curr Pharm Res 2014;6:61-5.

23. Raut NA, Gaikwad NJ. Antidiabetic activity of hydro-ethanolic extract of Cyperus rotundus in alloxan induced diabetes in rats. Fitoterapia 2006;77:585-8.

24. Al-Amin ZM, Thomson M. Anti-diabetic and hypo lipidaemic properties of ginger (Zingiber officinale) in streptozotocin-induced diabetic rats. Br J Nutr 2006;96:660-6.

25. Calabrese C, Berman SH, Babish JG, Ma X, Shinto L, Dorr M, et al. A Phase I trial of andrographolide in HIV positive patients and normal volunteers. Phytother Res 2000;14:333-8

26. Suebsasana S, Pongnaratorn P, Sattayasai J, Arkaravichien T, Tiamkao S, Aromdee C. Analgesic, antipyretic, anti-inflammatory and toxic effects of andrographolide derivatives in experimental animals. Arch Pharm Res 2009;32:1191-200.

27. Vedavathy S, Rao KN. Antipyretic activity of six indigenous medicinal plants of Tirumala Hills, Andhra Pradesh, India. J Ethnopharmacol 1991;33:193-6. 